\title{
The Fascist Body in Contemporary Portuguese Narrative
}

\author{
José N. Ornelas
}

\begin{abstract}
Este estudo examina, através de uma leitura de vários textos pós-revolucionários, o modo como o fascismo fundamenta ou centraliza metaforicamente as sua ideias e os seus princípios básicos no corpo. O corpo, na conceitualização do discurso fascista, é o foco do poder e um espaço de disputa. As formulaç̃̃es da retórica fascista assentam fortemente numa correlação entre um corpo saudável e uma mente saudável. Tanto a incorporação do corpo como todo um reportório de símbolos e mitos passadistas e nacionalistas por uma ideologia autoritária e repressiva revelam as verdadeiras intençð̃es do fascismo: a contrução de um discurso de regulamento e de homogeneização dos valores e principios nacionais portugueses. O objectivo fundamental dos textos pós-revolucionários é expôr o modo como o fascismo usa e abusa do corpo e de toda uma mitologia nacional numa suposta política de regeneração e de restauração fundamentada na repressão e na destruição da liberdade e da dignidade do indivíduo.
\end{abstract}

Since the $25^{\text {th }}$ of April 1974 Revolution, many Portuguese narratives have focused on Portugal's immediate historical past, specifically the era associated with Salazar and the Estado Novo, the fascist period. These works of fiction have dealt with different aspects and experiences of the period and, even different decades, but all of them symbolically portray the period as a dark cloud passing over Portugal, that is, a cloud associated with supposedly moral and cultural revival, patriotism, belligerent nationalism and glorification of the past, usually to hide the shortcomings and failures of fascism. Among the many literary texts that have dealt with this bleak period of Portuguese history, one finds José Saramago's The Year of the Death of Ricardo Reis and "Cadeira," Mário Cláudio's Tocata para Dois Clarins, Eduarda Dionísio's Retrato dum Amigo Enquanto Falo, José Cardoso Pires's Ballad of Dogs' Beach, Manuel Alegre's Com Alma, Baptista Bastos's O Cavalo a Tinta-da-China, Lídia Jorge's $O$ Dia dos Prodígios and $O$ Vale da Paixão, Teolinda Gersão's Paisagem com Mar e Mulher ao Fundo, António Lobo Antunes's Fado Alexandrino, Nuno Júdice's Vésperas de Sombra, and many others. Most of the narratives of the Colonial Wars have also taken into account the so-called rhetoric of empire formulated by Salazar and his fascist cohorts directly responsible for the African debacle and, therefore, had to deal with the ideological dynamics of fascism. All of these texts, including those focusing on the Colonial Wars, were written to unmask the articulation of a Portuguese nation constructed as an inherent political destiny that derives its essence from God and Christianity, as well as from the evocation of examples from a petrified past. Portuguese fascism may have felt that it was necessary to uphold Christian principles and the glory of a mythic past as the basis for social cohesion, the revival of spiritual values and a national reawakening, but, as contemporary narratives reveal, the use of these discourses was just the rationale behind fascism's wanton destruction of liberty and life or what Dave Renton, in Fascism: Theory an Practice, labels fascism: a "specific form of reactionary mass movement" (3) that is the enemy of democracy and denigrates human life.

Although there is not a general consensus regarding an empirical definition of fascism, there are certainly many concepts and theories that can be singled out that give a general interpretation of the significance of fascism in the cultural and political life of Portugal for 
almost fifty years from 1926-1974, as well as in many other European countries. In the case of Portugal, as José Mattoso stresses in História de Portugal: O Estado Novo (1926-1974), the so-called fascist political revolution was based on several fundamental parameters including the acceptance of strong nationalistic and authoritarian reactions already prevalent in Europe, the refusal of the liberal, democratic and parliamentary fundamentals of the State because of its association with social and political disorder, the institution of a corporate and social State in order to structure harmoniously all the collective interests of the citizens, and the creation of a strong State and its right and obligation to coordinate the economic and social life of the nation (197-202). In many ways, albeit with certain differences because of the unique political situation of Portugal and the vision of its fascist leader Salazar, the key concepts and theories of the Portuguese fascist program are aligned with the specific goals and forms of fascism that appeared in other European countries, which tried to organize political power and integrate all social forces in a organic and genuine unit subordinated to the interests of the nation. Other key concepts and theories associated with fascism in general are: a revolt against positivism and a reaction against rationalism, liberalism, modernism and materialism or, better yet, as Benito Mussolini was so fond of saying, against the philosophical and political project of the French revolution or the ideals for which it stood; sanctification of the nation as well as nature; aggressive nationalism, patriotism and exaltation of past national glory; revolt against the cultural crisis and the moral degradation and disease prevalent in Portugal and Europe in the period after World War I; regeneration and restoration of the state, as well as of the individual, as an essential component of the state apparatus; revival of philosophical vitalism and idealism; "the will to power, rooted in a vitalist conception of group energy" (Fascism 12); the charismatic and totalitarian nature of fascism; and the glorification of war and the idea that war is a fascist universal or the highest form of cultural celebration reserved strictly for cultured males. In addition, all the different national types of fascism integrated another key conceptualization in their discourse: a concern with the body, both in its male and female forms. The body was viewed as a locus of power plays and as site of contestation. It would seem peculiar that fascism, which was so preoccupied with the pursuit of fascist truth and knowledge, would even consider the body a key element in its ideological theorization since it had always been regarded as a site of unruly passions and appetites. Fascism was indeed opposed to unruly passions and appetites, and all kinds of deviant sexual practices, and in principle it did reject the sexualized and the erotic charged body. Its idea was to create a self-contained, well ordered, pliable and repressed body (white and male) whose sole objective was to serve the cause and the interests of the nation and preserve its wholeness. In the conceptualization of fascist discourse, there was constantly a strong correlation between a healthy and strong body and a healthy mind. The old bourgeois society, according to the fascists, was decadent and sick because it was lead by sick, feeble, effeminate and sexualized leaders. Diseased bodies of leaders reproduce decadent forms of government. The traditional Cartesian mind/body split with the body being the devalued term was not the image that fascism wanted to construct. Fascism did see a healthy body in its desexualized and deeroticized form and in its harmonious relationship with the mind as a path to a higher and more valorized and vital form of truth and knowledge leading up to the full realization of the natural spirit of fascism. It is interesting to note that nature/body and spirit are never present in fascist discourse as dichotomous terms; rather they always appear as complementary terms.

Many critics have commented specifically on the politics of the body in fascist discourse and the fundamental role it plays in its conceptualization. Mar Neocleous in Fascism claims that fascist discourse had a fascination and "an obsession with virility and the health of each member of the society and, relatedly, a vision of society as a collective body. Mediating between these two issues is the body of a leader, at once both an individual 
human being and, as a representative and leader of the nation, representative of the virility and health of the nation" (82). He adds later: "The fetishization of the body and the aesthetics of physical perfection and stylish virility are specific to fascism and the fascist political project. It is partly a result of treating the human body as a 'political space', as the Nazi sports theorist, Alfred Baeumler, puts it" (82). For Steve Pile, in The Body and the City, "[f]ascist discourse is continually vigilant of incursions across the boundaries between desire and sexuality: where desire is desexualized and sexuality is desensitized" (206). Klaus Theweleit, one of the foremost theorists and critics of fascism, affirms that male sexuality in fascist discourse was placed essentially at the service of destruction. It served no other purpose since any form of contact with the female body and/or the masses would lead to the dissolution and the waste of the boundaries of the male body (7-35). Theweleit argues that "the core of fascist propaganda is a battle against everything that constitutes enjoyment and pleasure. Pleasure, with its hybridizing qualities, has the dissolving effect of a chemical enzyme on an armored body. Attitudes of asceticism, renunciation, and self-control are effective defenses" (7).

The body as a political space where virility, strength and health could be inscribed was a hallmark of fascist rhetoric. There was a strong correlation between a virilized body and a virilized nation. However, this virility must not be confused with sexuality or eroticism. Only natural and healthy sexual acts were accepted by fascist rhetoric. In reality, one of the central tenets of fascist discourse with respect to the body was the death of sexuality understood as pleasure. A body that is virile, willful, vital and full of life was the goal of fascism, but it also was conceived as a desexualized body. In fact, fascism did not permit any other positive discursive representations of the body, especially the sexed body. A sexed or eroticized body could not serve the natural spirit of the nation, the desired goal of fascism. Accordingly, such a body was viewed as being diseased and in urgent need of sanitization and cure in order for it to become whole, virile and healthy again. The feeling body in fascist rhetoric was really an absence. The feeling body as presence was metaphorically associated with sickness.

Of all the post-revolutionary works dealing with the fascist period, Teolinda Gersão's Paisagem com mulher e mar ao fundo is undeniably the text most concerned with the body as a locus for political, social and cultural power plays and with the constitutive role that fascist rhetoric plays in the construction of individual and cultural body images. In Gersão's novel, the feeling body or the sick body as presence "era uma permanente tentação de ceder à sujidade e à desordem" (Paisagem 85 ), which eventually leads to the very dissolution of the fascist body. Indeed, fascist rhetoric at the same time that it was fascinated by the virility and the vitality of the body because it served its programmatic aims and objectives also despises it. The feeling body was viewed through the prism of horror and repugnance; it was something to be repressed and denied lest it destroy the image of wholesomeness and vitalism that the fascist state was trying to portray. In Paisagem, for example, all excesses of the body bring upon Áurea, an elementary school teacher and the quintessence of the discipline of fascist discourse, a sense of horror and repulsion. She also considers that pleasure is a form of degradation and, consequently, she considers her moral duty to "manter-se incorruptível, acima do baixo gozo da carne" (88).

However, to attain the pure and idealized space of incorruptible bodies was not difficult at all in Portugal since the country had its "protector, paternal guide, professor, gentle potentate, one quarter sacristan, one quarter seer, one quarter Sebastião, one quarter Sidónio, the best of all possible leaders, given our character and temperament" (The Year of the Death of Ricardo Reis 238) hovering over its caste and virtuous citizens, guiding them in the ways of the spirit and warning them about the excesses of the flesh, excesses which would lead to the total disintegration and dissolution of the body and by extension, the body of the nation/state. The idea advanced by Stanley Payne that fascist ideology relied on an 
authoritarian, charismatic, personal style of command (Fascism: Comparison and Definition 7) in order to promote its metaphysical idealism and vitalism, its will to power, is also an idea that is incorporated into Portuguese post-revolutionary narratives to enlighten the phenomenon of the cult of Portugal's leader, Oliveira Salazar, and his role in the construction of a fascist nation. In Paisagem, Salazar can be both a liberating presence, a type of savior, or a castrating figure depending on whether the leader is being constructed by Áurea or Hortense. For Áurea, O.S. (Oliveira Salazar) is a charismatic leader, the incarnation of perfection, goodness and sainthood, a God-like figure who works incessantly and selfsacrifices for the well being of the nation and its citizens.

Entre a ira de Deus e os ventos da História ele levanta-se como um anjo para proteger o seu povo. Ele é um rochedo de granito, uma fortaleza inexpugnável, contra a qual as ciladas do inimigo não terão jamais poder algum. Está sentado numa cadeira de ouro e não sai nunca porque todos os lugares do mundo estão nele, ele é o alfa e o ómega, o princípio e o fim... Velai por ele, ó Deus, pois ele é a nossa segurança e a nossa força. (83)

In fascist parlance or in Áurea's view of the Portuguese leader, Salazar embodies the passion and the masculinity of the will in a man. He is the perfection of a utopian vision and the symbol of incorruptibility; he is also the last defense against the threats of the disorderly and diseased masses and the feminization of culture.

However, as José Saramago so poignantly lays bare in "Cadeira", a short story about the famous or infamous episode of the fall of Salazar from his chair (his throne) that may have been the direct cause of the hematoma that eventually lead to his death in 1970, the body of the leader, Salazar, metonymically represented by the chair in the short story, has already been invaded by the desiring forces of the unconscious, the woodworms. In almost all discursive representations of Portugal during the fascist period, there was this image of Salazar conjoined to his chair, a symbol of power and domination. Reading "Cadeira" one has the sense that the chair has become Salazar or vice-versa; the chair and Salazar have essentially become undifferentiated. Both the chair and the supreme leader of the nation have also two separate entities: one that is interior and the other exterior. The exterior, the image for public consumption and which thrives on domination, is the machine-like body that struggles against anything associated with enjoyment and pleasure because of its fear of decay, disease and total dissolution. The exterior is the masculine concept of culture. The interior, associated with the desiring unconscious, is the counterpart of the masculine concept of culture; the threat always exists that the interior may erupt and seep into the exterior body armor and destroy it. Thus, the interior must be repressed, dominated and exterminated. Encoded with femininity, the space of excesses and unruly passions or the hidden space where the woodworms labor incessantly in order to penetrate the exterior body armor, be it a chair or Salazar's body, the interior world finally accomplishes its mission. The interior world frees itself finally from the space where it has been incarcerated; it emerges into the exterior, and causes the dissolution of the body armor. Saramago, in "Cadeira", parodies the decomposition of the chair, the emblematic symbol of the exterior body of Portugal, as it is being slowly devoured internally without even realizing it. The woodworm, the narrator is not exactly sure where,

se introduziu naquela ou noutra qualquer parte da cadeira, de qual parte depois viajou, roendo, comendo e evacuando, abrindo galerias ao longo dos veios mais macios, até ao sítio ideal de fractura, quantos anos depois não se sabe, ficando porém acautelado, considerada a brevidade da vida dos coleópteros, que muitas 
terão sido as gerações que se alimentaram deste mogno até ao dia da glória, nobre povo nação valente. (17)

Just as fascism had fed on an idealized version of Portugal as a noble people and a valiant nation, the woodworm also feeds on a fascist body that eventually disintegrates. For the new heroes, the woodworms or those responsible for the dissolution of the fascist body, there will also be a new day of glory associated with the construction of a new body politic.

On the day of the tragicomic fall, as the narrator in an extremely ironic tone recounts in "Cadeira", Salazar approaches the chair not paying close attention to it. "Vê-a de longe o velho que se aproxima e cada vez mais de perto a vê, se é que a vê, que de tantos milhares de vezes que ali se sentou a não vê já, e esse é que é o seu erro, sempre o foi, não reparar nas cadeiras em que se senta por supor que todas são de poder o que só ele pode" (22). The body politic personified by Salazar or through metonymic extension by the chair is totally oblivious to the havoc being produced by the inner drives, that is, the devastation wrought upon the body politic by the forces that oppose it or feed off it, and wish to give it a different body configuration. The exterior feels so secure in its body armor that it simply fails to see the enemy within, the decaying interior body. Ironically, it is only this decay that is truly alive since it is from the unconscious drives, life itself, that emanate the desires that will eventually overflow the rigidity of the armor and create a new body politic.

The cultural evaluation of corporeality present in fascist discourse was very much based on hierarchical, epistemological and ontological categories that guaranteed the superiority of the male body over the female body. In reality, the realm of fascist imagination associated woman and the fluidity of her body "with all that might threaten to deluge or flood the boundaries of the male ego" (Theweleit, XVII). Therefore, it repudiated femininity in all its sexual and erotic manifestations. Likewise the masses were invariably encoded with femininity, lust, bestiality, dissolution and contagious pleasure, all threats to the male body in the same way that woman was a threat to male armor. The only woman acceptable in the realm of fascism was the one who had no sexual organs, that is, woman as a virginal body and as untrodden territory or woman elevated to male status, exactly what Áurea is and has accomplished in Teolinda Gersão's Paisagem com Mulher e Mar ao Fundo. She looks at pleasure as a form of degradation and desires fervently to maintain herself incorruptible and above all the base pleasures of the flesh. Needless to say, she can do this without much of an effort "porque era desligada do corpo, como se não fosse de carne mas de outra matéria mais sublime, tinha um nome profético, Áurea, de ouro, a feita de ouro" (88). Her ultimate goal is to "[d] ominar o corpo com os grilhões do espírito. Através da renúncia ao corpo, transmudar misticamente em ouro a carne maléfica e corrupta" (89).

Paradoxically, as fascism extols the concepts of virility and manliness as central to the construction of its political space, it is also radically anti-eros. Fascism is extremely uncomfortable with the body as flesh-and-blood, a body that it associates with the female and the masses. To counteract the negative and disintegrative bodily forces of the other, the male body must undergo constantly a variety of mental and physical self-regulatory operations in order to preserve its wholeness and integrity (Theweleit, xvii-xviii). According to Theweleit "the most urgent task of the man of steel is to pursue, to dam in and subdue any force that threatens to transform him back into the horrible disorganized jumble of flesh, hair, skin, bones, intestines, and feelings that call itself human" (160).

The male may be strong, healthy and virile, as Salazar is in Paisagem, but he must repress and deny his sexuality since it leads eventually to physical degeneration. To preserve his virility and strength he must lead the life of an angel and/or a saint, that is, an asexual existence devoid of any sensual and/or erotic excesses. Salazar is aware, just as Áurea is, that pleasure and culture rise and fall proportionately. Consequently, both feel that the 
emancipation of woman will destroy culture because the female is associated with unruly passions and appetites. As a disciplined fascist, Áurea will ensure through her actions that Salazar and all those virile Portuguese fascists are not transformed back into that horrible disorganized jumble of flesh where man becomes woman. In reality, Áurea truly scorns and condemns all forms of erotic pleasure, as well as the feminization of culture because she strongly believes that they will lead to the degradation and decadence of society. In her view, eroticism is always unproductive, unhealthy and sterile. Consequently, she gears her actions towards stopping the disease of emancipation from spreading throughout the nation. Áurea really makes emancipated woman the negative pole of nationalist fascist discourse; this woman is clearly the adversary that threatens the unity, health and productiveness of the fascist state. In a sense, the emancipated woman is the menacing Other for Áurea, a sort of metaphysical force of evil. It is in contrast to this figure of negativity that the virile and productive male fascist is constructed and nationalism sprouts forth. Áurea clearly establishes a strong link between nationalism and anti-eroticism and anti-feminization of culture. In her discourse, there is a constant contrast between the productive and virile images of the Nation-Self and the decadent figures and images associated with eroticism and the feminization of culture, the forces of Portuguese spiritual decadence.

Era verdade, sim, começava a grassar entre as pessoas uma espécie desenfreada de loucura, as mulheres queriam saber tanto como os homens, não admirava que eles não as amassem, elas competiam com eles, queriam roubar o seu lugar no mundo, as mães abandonavam os filhos, desertavam do seu posto, iam todas para a rua [a symbol of dissolution and disorder] e não ficava ninguém em casa, as vítimas eram sempre as crianças, as mães tomavam contraceptivos [associated with the decline of culture] para terem amantes livremente-a sabotagem à própria natureza, a desobediência à lei de Deus e da Igreja, até isso, oh Deus, até isso elas faziam,- - a culpa do descalabro e do mal era toda das mulheres, das mães. (86-87)

What are Áurea's arms against the dreaded disease of emancipation, which would eventually lead to the destruction of the nation? Her arms are sacrifice, self-control, selfdenial, renouncement, repression, suppression, prohibition, vigilance and asceticism. With these arms she will definitely be able to control the excesses, the desires and the needs of the body so that it remains pure, healthy, strong and even virile. Unlike other women in Portugal, Áurea had understood quite well a fundamental maxim of Salazar's ideology: "As mulheres não compreendem que não se atinge a felicidade pelo prazer, mas sim pela renúncia." (Baptista-Bastos 214). She also readily accepts one of the most fundamental but also most perverse maxims of Portuguese fascism that a mother's greatest sacrifice and duty is to guide her son to his loftiest and noblest act, which is to give his life in defense of the homeland (The Year of the Death of Ricardo Reis 222). As an elementary teacher, she has the opportunity to indoctrinate the youth of Portugal in the aforementioned principles of selfdenial, sacrifice and duty, that is, to convince her students to work solely for the nation with the ultimate goal of preserving the virility and the vitalism of the nation. In fact, she is an apologist for the ideal type Salazarist ideology centered on God, Fatherland, Family, and Work. As a teacher, Áurea follows official guidelines regarding the role the classroom must play in the indoctrination of Portuguese citizens. It is her opinion that elementary school teachers must teach the value of obedience and resignation, "as well as the values of an 'organic' society that had no knowledge of conflict or 'politics' clearly reserved for a paternalistic elite headed by Salazar" (Pinto 197).

As a female, Áurea is also cognizant of the fact that the body-space of fascism is continuously under threat of fragmentation and dissolution since it can be and is easily engulfed and annihilated by a female body that classically has been represented as saturated 
with sex. Consequently, she spares no effort in attacking the feminization of society and in insisting that women and also men suppress any desire bubbling up within their bodies so that they never overflow the sexual categories or, better yet, the social roles assigned to them. Only through these efforts can the destructive and decaying forces of liberalism and democracy be stopped from gaining ascendancy in Portugal. In her very best reactionary judgment, the renewal of the nation will only occur, if the fascists, the embodiment of asexuality, are at the vanguard of the struggle.

Both Teolinda Gersão and José Saramago, as their narratives indicate, are fully capable of using the subject's corporeality as a framework to problematize the ideology of fascism. They show that fascist rhetoric is concerned with the inscription of the body: the body as a sign system, a text endowed with specific meaning. This body, through many modes of corporeal inscription, was molded to the prevailing exigencies of fascist power, and it was constituted for its social, ideological and cultural requirements. Elizabeth Grosz in Volatile Bodies has addressed the very complex issues of the relationship between power and body and also the many ways by which power molds and disciplines the body. She claims that

[t]he body is indeed the privileged object of power's operation: power produces the body as a determinate type, with particular features, skills and attributes. ... Power does not control the subject through systems of ideas-ideologies-or through coercive force; rather, it surveys, supervises, observes, measures the body's behavior and interactions with others in order to produce knowledge. It punishes those resistant to its rules and forms; it extracts information from its punitive procedures - and uses this information to create new modes of control, new forms of observation, and thus new regimes of power-knowledge as well as, new sites of resistance. (148-149)

Most post-revolutionary writers understand quite well how the body is produced by relations of power, as well as through and by history. Consequently, the body has become, in many contemporary narratives, the site for understanding subjectivity and sexuality during the Estado Novo period and for questioning long-held fascist presuppositions and assumptions which contributed to the cultural, political and social effacement of many groups, especially women and the lower, uneducated classes. These groups were simply used to further the agenda of the fascist apparatus. They were the masses that needed leading, the mediocre majority from whom Oliveira Salazar, the country's leader and the very embodiment of world-spirit, obtained his means of subsistence.

Aside from the narratives analyzed previously, there are many others that have focused on the body as a site to understand fascism, a system intent on producing a subject whose sexuality and subjectivity are sanctioned and institutionalized by fascist authorities. In other words, it is a system whose main objective is the construction of a body acquiescent to the internal and the external exigencies of fascist ideology. These post-revolutionary narratives clearly show that fascist rhetoric had the ability to regulate social, political, economic, sexual and cultural life through a "micropolitical regulation of the body" (Grosz 151). As mentioned previously, at the center of the regulation of the body of the masses stood usually a charismatic figure, a leader of great presence who exercised a great hold over the body of the masses. Mark Neocleous claims that fascism rests on "a politics of the body, through an obsession with virility and the health of each member of the society and, relatedly, a vision of society as a collective body. Mediating between these two issues is the body of a leader, at once both an individual human being and, as a representative and leader of the nation, representative of the virility and health of the nation" (81-82). Salazar, the Portuguese leader, believed that he had been chosen by destiny to assume a leadership role in the country, and that he had the vision and the character to be an effective leader and to nurse 
the nation back to health. Consequently, he felt that he had a right to hold the destiny and the course of the nation, as well as the masses in his hands. Moreover, he was willing to selfsacrifice for the benefit of the nation/state and his followers.

Salazar's power or sway over his followers deviated radically from that of Adolph Hitler. The Nazi leader, as shown in Saramago's O Ano da Morte de Ricardo Reis, derived his power from his oratorical abilities and his capacity to express the desires and the feelings of the German people at a time of convulsion in their history. Hitler's hold over his subjects was hypnotic; there were overtones of eroticism in his relationship with the masses. The crowds in the presence of the Führer appear, in $\underline{\mathrm{O} \text { Ano }}$, as an eroticized mass of convulsing and gyrating bodies ready to have a collective orgasm. This mass erotic display, this erotic and frenetic rapture, which occurs whenever the leader makes his presence felt concludes with an orgiastic explosion. Saramago refers to "pregnant women throbbing with swollen wombs and heaving breasts, men endowed with strong muscles and wills, all shouting and applauding until the Führer comes to the window, then their hysteria knows no bounds, the multitude cries out with one voice, Heil" (222). Unlike Hitler who had a magnetic presence as he addressed crowds and had the capacity to establish an almost erotic relationship with his audience, Salazar, as he is portrayed in post-revolutionary narrative, resembles mostly a father-like figure, a man who has dedicated his life to the service of his extended Portuguese family (the nation as a whole), that is, someone who is a protector and a savior of the country's citizens and assumes a paternalistic attitude towards them. In certain instances, however, Salazar holds the same erotic fascination in the face of crowds as Hitler. Nuno Júdice affirms, in Vésperas de Sombra, that the crowd as it listened to one of the dictator's speech "embora não houvesse mulheres dentro dela, era um ser feminino, que gozava passivamente essa relação de domínio absoluto, até ao orgasmo, quando a última frase emblemática obrigava ao climax da última saudação" (21). Regardless of this particular representation of the dictator as an erotic body, Salazar is portrayed as a man who possesses God-like qualities and has the intellectual qualities to guide the citizenry in its proper path. In addition, he is shown as having the ability to restore the country's fortunes, "to provide a new political doctrine, to install faith, enthusiasm, and confidence in the future" (The Year of the Death of Ricardo Reis 256) by inflaming the winds of fanaticism and of the civilizing role of the Portuguese in the world. However, as Saramago reveals throughout his novel, Salazar's image as well as his many accomplishments are distorted by the zeal and the fanaticism of nationalism, which have dimmed the intelligence of Portuguese citizens.

Likewise in Teolinda Gersão's Paisagem, the protagonist, Hortense, as well as many other characters view Salazar as the evil angel of history and consider his fascist doctrine and his construction of a new Portugal an escapist daydream to further estrange and alienate Portuguese citizens from their own History, from present reality. The positive image that the dictator wishes to convey about himself and the country to the citizens of Portugal is really deceptive; it is an image/mirage whose intention is to neutralize all aspirations and struggle for change-it tries to freeze the perpetual motion of so-called progress-and to manipulate the Portuguese into accepting a state of idealized and contented conformism. Going against the grain and believing in the perpetual motion of progress and that she is being excluded from the construction of culture/History, Hortense not only struggles for freedom and liberty and tries to destroy the conformist thread of fascism with all the arms at her disposal but she also unmasks the image of the benevolent and paternalistic dictator. The image that she conveys to the reader is that of an oppressor and a barbarian, the reverse side of the image or the negative of the picture that had been so well crafted by fascist ideology. In Portugal, no feast of progress and freedom can truthfully be celebrated because 
por detrás de tudo, cortando a alegria, cortando a vida, a mão de O.S., levantandose acima de todas as coisas, fazendo parar o país, parar o tempo, retroceder os séculos atrás, a sua mão parava o tempo da mudança e espalhava a areia negra do medo, apertava em torno das casas a mordaça do silêncio, a sua mão castradora retirava ao povo a força da revolta, as pessoas dormiam de olhos abertos, atravessando o tempo sem tocar-lhe, cumprindo automaticamente o dia-a-dia, repetitivas, sombras gastando a vida em exercícios de resignação e obediência. Os sus pés tinham sido cortados e elas não tocavam mais o mundo. (Paisagem 66)

This repressive and castrating body of the dictator is responsible for the construction of the mutilated bodies that Teolinda Gersão describes. Fascism takes possession of Hortense's body and renders it meaningless in historical time; it is no longer a body politic. However, Hortense, through small acts of disobedience, refusal, non-submission, rage and aggression, constantly resists and challenges the surveillance and the repression to which her body is subjected. As the protagonist of Paisagem finds out, it is no easy task challenging, fracturing or sabotaging the suffocating space of Salazar for everywhere there is an Aurea, the body of the surveillant, the individual whose mission is to affirm the political order and defend it from those who try to subvert and/or undermine it. Áurea and others like her, e.g., Victor in The Year of the Death of Ricardo Reis and Elias Santana in José Cardoso Pires' Ballad of Dogs' Beach, hold a privileged point of view in the fascist body politic. They are the surveillant and/or gazing bodies, the individuals in a position of authority who force other Portuguese citizens to enter into an economy of uneven exchange, which allows the state to maintain a sense of mastery and control over their movements, gestures and speech. The gazing or observant body makes it possible to explore and map the whole of the Portuguese human territory, which allows the state to maintain its hold on power.

Several post-revolutionary narratives do detail this intimate relationship between power and visual surveillance. The body of the surveillant or the gazer may play different roles, but always its main objective is to suppress all acts of resistance and repress the others of the system so that the relations of power inherent in fascist discourse remain intact. Surveillance can, at times, be directed against one's own self or body, as is the case with Áurea in Paisagem. She needs to be vigilant against all forms of evil and to be on guard against corruption so that they are rendered harmless and do not threaten her body. For her, to repress is to educate; a repressed body is an educated body, the body that best serves the aims of fascist rhetoric. However, most of her surveillance techniques are directed against the others, especially her students. Her motto is to "[n]ão deixar as crianças sentir nem pensar livremente, mas ensinar-lhes o que deviam sentir e pensar. Porque acerca de tudo elas tinham sentimentos despropositados, excessivos, sem controle, que era preciso orientar para o caminho certo" (Paisagem 89 ). The fact that she has the ability to control and to direct her students, her objects of surveillance, confers upon her great power. She is also very aware of the power that she has gained through her surveillant role in life. In a similar vein, Hortense, as the observed, feels that visibility is a trap since it denies her freedom of expression and causes her to be powerless.

Surveillance and observation are fundamental to the proper functioning of the fascist system. Without the knowledge acquired through constant surveillance, fascism would never have been able to construct an ordered space to inhabit. Educators, the secret police, paramilitary groups, the censors, as well as many other individuals were involved in all the various aspects of surveillance. Many of these same surveillance tactics were also appropriated by those opposed to the fascist state, as Ballad of Dogs' Beach abundantly makes clear. The surveillant is everywhere and nowhere at the same time. Even when he is nowhere, his power reaches everywhere. The observer is almost like the invisible hand of the 
repressive fascist state, as Ricardo Reis finds out. Victor, his observer, after his initial contacts with his adversary Ricardo no longer feels a need to be visible. Since he constantly reeks of onions, the smell of onions is enough to control Ricardo's movements and actions. It is control of the other through the suggestive power of onions. After returning home from a political rally, Ricardo Reis as he begins "to brush his jacket and trousers, he found himself inhaling the smell of onion, how strange, he could have sworn he had been nowhere near Victor" (344). There are other occasions in the novel where the smell of onions suggests the absent presence of Victor.

Surveillance is one among many other methods utilized by the Portuguese fascist state to construct a compliant, obedient, conforming and submissive body, a body that would always defend the interests and the ideology of the state. Unquestionably, the ultimate goal of surveillance is to construct a body politic that speaks with one voice and accepts without any questioning fascist doctrine and its aims. To achieve such a social and political body, the body must be constantly supervised, regulated, constrained and regimented. Only then is there a guarantee that it will not deviate from the basic tenets of fascist ideology, and that the self will deny itself to become one with all the others, as it happens at the political rally that Ricardo Reis attends. At the rally, one of the speakers claims that "we have gathered here as one man around Salazar" (343) and during another instance upon hearing the word legion from a different speaker the crowd at the rally "rises to its feet once more, always to a man" (343). In Vésperas de Sombra, the narrator also points out that unison and order prevail at a political rally: he claims that the multitudes are "agindo em uníssono com a vontade do Chefe, subordinando todos os interesses individuais à vontade comum, mais forte do que 0 próprio homem" (21). Both narrators are quite correct in stating that the crowd acts as if it were one man, and that all individual wills are subordinated to the will of just one man. There are no women present at the rally; it is an exclusive event for those who have a say or think they have a say in how the nation is to be constructed and governed. Therefore, it excludes all women. Within the conceptual framework of fascism, women were assigned specific roles within the system: they would be the producers of children and they would stay at their place, which is the home within the family unit. The public space is certainly not one of their spheres.

Besides the objectives of surveillance as described above, surveillance is also used to weed out from the system those bodies it considers weak, shoddy, diseased and effeminate, as it seems to be the case with Ricardo. For Victor, Ricardo is the perfect symbol of the decline of the national character and the morality of the nation. He is excess within the context of fascist ideology since his character is an affront to the virility and the will of the collective body. He is like an alien species that threatens to consume the whole and, consequently, his body must be literally dug out.

Just like Victor, Elias Santana, a Criminal Justice inspector, in Ballad of Dogs' Beach is also obsessed with the health of the nation. He wants to rid it of its moral and social pollution by cleansing those he considers polluters of the body politic: opposition figures, those involved in clandestine operations, as well as their lovers and their many accomplices. Ironically, Elias Santana, the supposed defender of a virile and healthy fascist discourse and someone who constantly focuses his attention and polices and maintains surveillance over those he considers deviate and effeminate, is much sicker and more morally diseased than those he assumes to be polluters of the nation. Elias, as his actions indicate, is a morally weak and sexually depraved individual who goes as far as to peep into Mena's cell while she is undressing. He is in charge of interrogating Mena who has been implicated in the assassination of her lover, major Dantas Castro, an opposition figure. In spite of Elias's polluted character, there is a powerful and sickly obsession, on his part, with the health of the nation. In Elias Santana's view it is indeed appropriate and correct to weed out from the 
body politic those who are unwanted and/or are sick. As a defender of fascist ideology, he believes quite strongly that "the elimination of those objects not fit to live in the community is an entirely legitimate political exercise" (Mark Neocleous 86). A sick body trying to target state power against other supposedly sick bodies seems like the ultimate perversion and irony. In reality, fascism is a system intent on weeding out allegedly diseased bodies for the preservation and the propping up of likewise diseased bodies, those of the fascists themselves, while all along believing and propagating the idea that fascists possess healthy and virile bodies.

Although Portuguese fascism was mistrustful of the body since it was a site of unruly passions and appetites, which thwarted the pursuit of truth and knowledge, many postrevolutionary narratives have clearly made public the fact that fascism constantly fought over the inscription of the body and the role it should play in the formulation of its discourse. I would suggest that it was precisely because the body was considered the site of unruly passions, excesses and appetites that the discourse of the body became a central tenet in the elaboration of fascist ideology. As Teolinda Gersão clearly demonstrates in Paisagem, the fascist regime always posits a healthy, virile and strong body to mark its difference from the modernist and liberal state, which, according to the fascists, posits a decadent, diseased, sick, sexed and effeminate body as a conceptual framework for its discourse. For the fascist regime, only the body as absence, that is, the repudiation of one's own body in terms of its emotions, feelings, and sexual desires could serve the aims of the system. Given the association of the female with emotional excess, passion and sexual appetite, there is a strong fear of the feminine for it may overflow the boundaries of fascist ideology. Women are perceived as a danger to the established order and, consequently, their bodies have to be kept under constant surveillance, they have to be policed and regulated. The removal of women from the public sphere and their assignment to the space of producers of children and overseers of the family unit reveal that the female body is a threat to the wholeness and integrity of the system. Hortense, in Paisagem, and to a great extent Lydia, in The Year of the Death of Ricardo Reis, use their sexed and emotional bodies in their struggle to subvert and to collapse the fascist system. However, most of these endeavors meet with frustration since for every woman who uses her body to rupture the engulfing universe of fascism, there are countless others who flee from pleasure and desire and therefore reinforce through their actions the armored body of fascism. The universe of fascism is full of characters such as Áurea, a woman who lives a life of renunciation, self-control and denial and who helps defend the system through her actions, words and behavior from the chaoticized and pleasure-seeking bodies whose ultimate and only goal is, in her personal opinion, to devour and contaminate her beloved and virtuous fascist regime.

As post-revolutionary narratives point out, more than just cadres who support fascism are needed for it to survive for a long period of time and for it not to be engulfed by lust, pleasure, uncivilized crudity and licentiousness, the very enemies of fascism. It takes more than an Áurea or thousands of like-minded people to maintain intact the body armor of fascist ideology. Only a strong and effective leader who understands the principles and tenets of the fascist regime can prevent its fragmentation and dissolution. Fascists really believe that they have found their true leader when Salazar assumes power. He has supposedly the capacity to voice their political and social aspirations and desires and he also has the intellectual capability to restore and regenerate the nation. He is well versed in the ways of higher culture and therefore has the political expertise to determine and sanction the principles by which the nation would be guided: he would be the noble, moral, rational and spiritual compass of a new and regenerated nation. His knowledge, his intellect, his power of persuasion would be crucial for the construction of many docile, conformist and submissive bodies, as exemplified by Áurea in Paisagem and Salvador and Dr. Sampaio in The Year of 
the Death of Ricardo Reis, as well as many other characters. Indeed, he may even have thought of himself as the moral, ideological and rational body by which the nation guided itself. Many events narrated in the novels analyzed previously definitely reveal that the country seemingly is speaking with one voice and that all men are just one man under Salazar's leadership. However, post-revolutionary narratives also make it abundantly clear that beyond the external façade of conformism and homogeneity, trademarks of the fascist regime, there is revolutionary ferment and a strong desire to break down the armor of the New State in order for people to achieve freedom and true emancipation. The fascist system is well aware of the subversive elements that are trying to undermine it, the so-called perverted and alien elements (the enemy within) whose actions seek the extermination of fascism. The body politic really lives with a primal fear of dissolution. Therefore, it reinforces itself with the likes of Victor and Elias Santana, the symbols of a sick, diseased and repressive state apparatus. Only through control of both the mind and the body is fascism able to maintain the people in check and hold onto power in Portugal for such a long period of time. Post-revolutionary writers constantly give credit for the longevity of the New State to the repressive organizational strength of the system rather than to the mass social and political appeal of fascism.

The fascist body politic unmistakably does need its extensive repressive apparatus, as well as an efficient propaganda machine whose main objective is to fight enjoyment, pleasure and difference. Without both of them, it cannot stop others from overflowing its boundaries. However, as events described in the works above indicate, even an extensive repressive apparatus cannot defend the fascist body politic from the onslaught of those who desire freedom and emancipation, those looking for an enlarged area of experience and new terms to define the subject, a subject invested with a sexed, passionate and emotional body. Saramago, in "A Cadeira," shows that no body remains forever the passive recipient of external stimuli. The body, the chair, may on the surface give the appearance that it is controlled by external stimuli. However, inside the body, there is tumult, chaos, and new life. The interior of the chair is a dynamic organism where the woodworms slowly chew their way to the exterior and eventually bring about the dissolution of the very structure of the body. The leader, Salazar, is so preoccupied with the perimeters of the body that he fails to see that the chair, a symbol of power but also of Portugal, is not a disemboweled organism but rather a living organism whose insides are in the process of rupturing the external façade of the chair. It has life, it has revolutionary zeal, and it causes Salazar to fall when he tries to sit on it, a fall that leads eventually to his death in 1970. A few years later, in 1974 to be exact, fascism finally has to face the reality that it simply cannot subdue the interior of the body, that institutional norms may have the ability to transform the body into an inscribed surface of events but they can never totally control it. The $25^{\text {th }}$ of April 1974 thus marks the end of the Portuguese experience with fascism. Once again the forces that cause the fall of the fascist system come from within. Naturally, I am referring to the armed forces. While the leaders are preoccupied with the perimeters of the body, the interior, which is supposedly enclosed in armor, overflows the external boundaries and ironically dissolves the fascist body politic. The military leaders finally come to the realization that all the tenets and principles of fascism are just a charade for the preservation of an elitist and autocratic ruling class. As more and more Portuguese soldiers fighting in the Colonial Wars are being sent to Portugal in body bags, the military leaders reach the conclusion that there is a greater duty in life than to take literally the fascist slogan "dar a vida pela pátria é um dever, e nada é mais honroso do que dar a vida por esse dever" (Vésperas de Sombra 71). The greater duty is to put an end to the whole mockery of the fascist state and its repressive and self-serving ideology, and build a new body politic, a new chair, which in addition to its perimeter has also an interior life. 


\section{WORKS CITED}

Baptista-Bastos, Armando. O Cavalo a Tinta-da-China. Lisboa: Temas da Actualidade, 1995.

Gersão, Teolinda. Paisagem com Mulher e Mar ao Fundo. Lisboa: Edições O Jornal, 1982.

Grosz, Elizabeth. Volatile Bodies: Toward a Corporeal Feminism. Bloomington: Indiana UP, 1994.

Júdice, Nuno. Vésperas de Sombra. Lisboa: Quetzal Editores, 1998.

Mattoso, José, ed. História de Portugal: O Estado Novo (1926-1974). Vol. VII. Lisboa: Editorial Estampa, 1994.

Milward, Alan S. "Towards a Political Economy of Fascism." Who Were the Fascists: Social Roots of European Fascism. Ed. Stein Ugelvik Larsen, Bernt Hagtvet and Jan Peter Myklebust. Oslo: Universitetsforlaget, 1980.

Neocleous, Mark. Fascism. Minneapolis: U of Minnesota P, 1997.

Payne, Stanley. Fascism: Comparison and Definition. Madison: U of Wisconsin P, 1980.

Pile, Steve. The Body and the City: Psychoanalysis, Space and Subjectivity. New York: Routledge, 1996.

Pinto, António Costa. Salazar's Dictatorship and European Fascism: Problems of Interpretation. Boulder: Social Science Monographs, 1995.

Pires, José Cardoso. Ballad of Dogs' Beach. Trans. Mary Fitton. London: Guernsey P, 1986.

Renton, Dave. Fascism: Theory and Practice. London: Pluto P, 1999.

Santos, Boaventura de Sousa. Pela mão de Alice: o social e o político. São Paulo: Cortez Editora, 1997.

Saramago, José. “A Cadeira.” Objecto Quase. Lisboa: Moraes Editores, 1977.

Saramago, José. The Year of the Death of Ricardo Reis. Trans. Giovanni Pontiero. New York: Harcourt Brace Jovanovich, 1991.

Theweleit, Klaus. Male Fantasies. Vol. 2. Trans. Erica Carter and Chris Turner. Minneapolis: U of Minnesota P, 1989. 